\title{
SCHLAP1 wt Allele
}

National Cancer Institute

\section{Source}

National Cancer Institute. SCHLAP1 wt Allele. NCI Thesaurus. Code C118203.

Human SCHLAP1 wild-type allele is located in the vicinity of $2 q 31.3$ and is approximately $225 \mathrm{~kb}$ in length. This allele, which encodes SWI/SNF complex antagonist associated with prostate cancer 1 long non-coding RNA, may play a role in metastatic prostate cancer. 